Arjan Lejour, Andrea Mervar and Gerard Verweij

\title{
The Economic Effects of Croatia's Accession to the EU
}

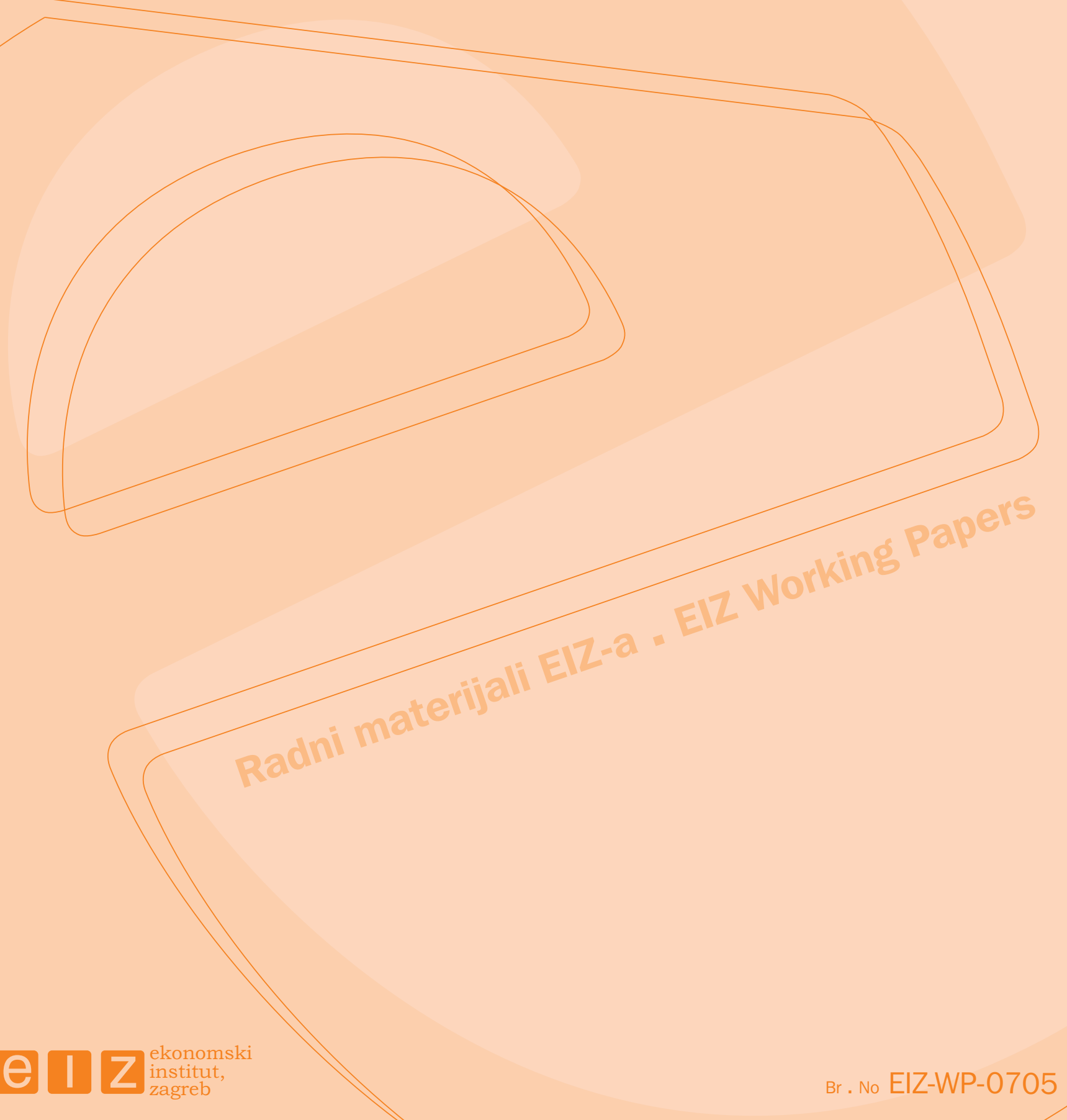




\title{
Radni materijali ElZ-a \\ EIZ Working Papers EIZ-WP-0705
}

\section{The Economic Effects \\ of Croatia's Accession to the EU}

\author{
Arjan Lejour \\ CPB Netherlands Bureau for Economic Policy Analysis \\ Van Stolkweg 14 \\ P.O. Box 80510 \\ 2508 GM The Hague, the Netherlands \\ T. 31703383311 \\ F. 31703383350 \\ E.A.M.Lejour@cpb.nl \\ Andrea Mervar \\ The Institute of Economics, Zagreb \\ Trg J. F. Kennedyja 7 \\ 10000 Zagreb, Croatia \\ T. 38512362200 \\ F. 38512335165 \\ E. mervar@eizg.hr \\ Gerard Verweij \\ CPB Netherlands Bureau for Economic Policy Analysis \\ Van Stolkweg 14 \\ P.O. Box 80510 \\ 2508 GM The Hague, the Netherlands \\ T. 31703383380 \\ F. 31703383350 \\ E.G.Verweij@cpb.nl
}

www.eizg.hr

Zagreb, December 2007 
IZDAVAČ / PUBLISHER:

Ekonomski institut, Zagreb / The Institute of Economics, Zagreb

Trg J. F. Kennedyja 7

10000 Zagreb

Croatia

T. 38512362200

F. 38512335165

E. eizagreb@eizg.hr

www.eizg.hr

ZA IZDAVAČA / FOR THE PUBLISHER:

Sandra Švaljek, ravnateljica / director

GLAVNA UREDNICA / EDITOR:

Valerija Botrić

UREDNIŠTVO / EDITORIAL BOARD:

Ivan Damir Anić

Željka Kordej-De Villa

Edo Rajh

Paul Stubbs

IZVRŠNI UREDNIK / EXECUTIVE EDITOR:

Josip Šipić

TEHNIČKI UREDNIK / TECHNICAL EDITOR:

Vladimir Sukser

Tiskano u 70 primjeraka

Printed in 70 copies

ISSN 1846-4238

Stavovi izraženi u radovima u ovoj seriji publikacija stavovi su autora i nužno ne odražavaju stavove Ekonomskog instituta, Zagreb. Radovi se objavljuju s ciljem poticanja rasprave i kritičkih komentara kojima će se unaprijediti buduće verzije rada. Autor(i) u potpunosti zadržavaju autorska prava nad člancima objavljenim u ovoj seriji publikacija.

Views expressed in this Series are those of the author(s) and do not necessarily represent those of the Institute of Economics, Zagreb. Working Papers describe research in progress by the author(s) and are published in order to induce discussion and critical comments. Copyrights retained by the author(s). 


\section{Contents}

\begin{tabular}{|c|c|c|}
\hline & Abstract & 5 \\
\hline 1 & Introduction & 7 \\
\hline 2 & A Glance at the Croatian Economy & 8 \\
\hline 2.1 & Historical Background & 8 \\
\hline 2.2 & Relations with the EU & 9 \\
\hline 2.3 & Economic Profile & 10 \\
\hline 2.3.1 & Key Economic Indicators & 10 \\
\hline 2.3.2 & Regional Disparities & 11 \\
\hline 2.3.3 & Trade Relations & 12 \\
\hline 2.3 .4 & Sectoral Structure & 13 \\
\hline 2.3 .5 & Export Specialisation & 14 \\
\hline 2.3.6 & Foreign Direct Investment & 14 \\
\hline 3 & Croatia's Accession to the EU & 15 \\
\hline 3.1 & Croatia's Development without Accession & 15 \\
\hline 3.2 & Accession to the Internal Market & 16 \\
\hline 3.3 & Improving Institutions in Croatia & 19 \\
\hline 3.4 & Other Issues & 21 \\
\hline 4 & The Economic Impact of Croatia's Accession to the EU & 22 \\
\hline 4.1 & The WorldScan Model & 22 \\
\hline 4.2 & Croatia's Accession to the Internal Market & 24 \\
\hline 4.2.1 & Macroeconomic Effects & 24 \\
\hline 4.2 .2 & Sectoral Effects & 26 \\
\hline 4.3 & Institutional Reforms in Croatia & 27 \\
\hline \multirow[t]{2}{*}{5} & Conclusions & 29 \\
\hline & References & 31 \\
\hline
\end{tabular}




\begin{abstract}
:
We explore the economic implications of Croatia's possible accession to the European Union. We focus on two main changes associated with the EU-membership: accession to the internal European Market and institutional reforms in Croatia triggered by the EUmembership. GDP per capita in Croatia is estimated to rise by about 1.1 percent as a result of accession to the internal market. In particular the textile and wearing apparel sectors expand. If Croatia succeeds in reforming its domestic institutions in response to the EU-membership, income levels in Croatia could increase even more. In particular, tentative estimates suggest that GDP per capita in Croatia could even rise by additional 8 percent. Overall, the macroeconomic implications for the existing EU countries are negligible.
\end{abstract}

Keywords: regional economic integration, general equilibrium model, gravity equations, institutional reform, Croatia

JEL classification: F13, F15

\title{
Ekonomski učinci pristupanja Hrvatske Europskoj uniji
}

\section{Sažetak:}

U radu se analiziraju ekonomski učinci mogućeg pristupanja Hratske Europskoj uniji. Pritom je pažnja usmjerena na dvije osnovne promjene povezane s članstvom u EU-u: jedna se odnosi na pristupanje zajedničkom unutrašnjem tržištu EU-a, a druga na institucionalne reforme potaknute članstvom. Procjene ukazuju da bi BDP po stanovniku u Hrvatskoj mogao porasti za oko 1,1 posto kao posljedica pridruživanja zajedničkom unutrašnjem tržištu. Posebno bi se značajni pozitivni učinci mogli odraziti u povećanju proizvodnje tekstilne industrije i industrije odjeće. Ako bi, kao rezultat članstva u EU-u, Hrvatska uspjela unaprijediti svoje institucije, razina dohotka bi mogla dodatno porasti. Okvirne procjene upućuju da bi BDP po stanovniku u tom slučaju mogao porasti za dodatnih 8 posto. Istovremeno su makroekonomski učinci pristupanja Hrvatske EU-u na njezine postojeće članice neznatni.

Ključne riječi: regionalne ekonomske integracije, model opće ravnoteže, gravitacijske jednadžbe, institucionalne reforme, Hrvatska

JEL klasifikacija: F13, F15 
Following the latest round of the EU enlargement that took place at the beginning of 2007, with Bulgaria and Romania becoming the twenty-sixth and twenty-seventh EU member states, the next prospective member appears to be Croatia. The increasing uncertainties regarding the EU absorption capacity and its future enlargements, as well as unsorted institutional issues, seem not to be affecting Croatia's current path towards the accession. Croatia's small size causes little concern about the impact it would have on the EU institutions, policies and its budget. Therefore, it has been repeatedly confirmed by EU officials that Croatia would join the EU as quickly as possible, provided that it fulfils all the required accession criteria (EurActiv, 2006). These criteria primarily relate to the progress with adopting and implementing the EU law. However, in some areas they also include broader political and economic reforms.

This paper focuses on the economic implications of Croatia's accession to the EU. In other words, the questions posed here refer to whether the accession will have positive or negative effects on Croatian macroeconomic well-being, its effects on producers across various sectors and the consequences for consumer welfare. Due to the population and output size, only negligible effects could be expected on the side of the EU. However, some sectors, especially those in the countries neighbouring Croatia, could experience more sizeable effects.

Although decisions on the EU accession have essentially been political ones, the economic benefits and costs of the EU integration might become one of the most decisive factors on the part of the Croatian citizens that will have to express their opinion regarding the accession on the referendum in due time and thereby make the final decision regarding the EU integration. Recent public polls indicate that positive and negative opinions are more or less equally balanced (EC, 2006c).

The analysis of the economic effects of EU integration is accompanied by a number of constraints that have to be taken into account when interpreting the results. First, it is not possible to explore (or, due to the high uncertainty, it is rather impossible to comprehend) all the economic costs and benefits of Croatia's accession to the EU. Additionally complicating the analysis is the fact that when evaluating the economic implications of the accession it is necessary to separate the processes of economic reforms that would take place without the accession from the processes that are solely due to the integration itself.

The approach taken in this paper does not attempt to exhaustively discuss all economic aspects of the Croatian accession to the EU, but it rather focuses on two policy reforms

\footnotetext{
"This paper has been published by CPB Netherlands Bureau for Economic Policy Analysis as a CPB document, No. 154, October, 2007 (http://www.cpb.nl). The research was conducted at CPB in February 2007 when Andrea Mervar visited CPB for contributing to this project. The authors benefited from useful comments by Stefan Boeters, Hugo Rojas-Romagosa, and Paul Veenendaal.
} 
that are dealing with the accession issues from different but complementary perspectives. The first simulation refers to the accession of Croatia to the common internal market while the second one focuses on the institutional reforms that should result from Croatia's compliance with the acquis communautaire.

In the case of the first simulation, we follow the approach used by Lejour et al. (2004) and Lejour and de Mooij (2005) by calculating the potential trade between the EU and Croatia from the estimated gravity equations across fifteen different sectors. A comparison between the actual and potential trade gives base for estimating the tariff equivalent of the non-tariff barriers to trade between the EU and Croatia. These barriers are then removed to simulate Croatia's accession to the EU internal market using the computable general equilibrium (CGE) model for the world economy - WorldScan - that is calibrated on the 2001 data. In the second simulation, we calculate the potential aggregate trade between Croatia and the EU in case the Croatian institutions improve. As in the previous case, the CGE simulation provides macroeconomic and sectoral effects in case trade is increased.

The rest of the paper is organised as follows. Section 2 gives a brief overview of the basic features of the Croatian economy, including historical developments and comparison with the EU members and candidate countries. Section 3 describes the baseline scenario and shocks that the Croatian economy might experience as a consequence of the EU accession. Section 4 briefly describes the computable general equilibrium model for the world economy - WorldScan - and discusses the impacts of different shocks on the Croatian economy. Section 5 concludes.

\section{A Glance at the Croatian Economy}

\subsection{Historical Background}

Up to the beginning of the 1990s, Croatia was one of the republics of the former Yugoslav federation and represented, together with Slovenia, its most developed part. Not being typically socialist, ${ }^{1}$ the Croatian economy faced the beginning of the 1990s and transition processes following the widespread collapse of socialism with certain advantages. Due to a fairly high income per capita, economic openness, a well-trained labour force and relatively developed markets for goods and services that were subject to only minor governmental intervention, Croatia satisfied credible preconditions for a rather smooth transition to a fully market-oriented economy. However, the subsequent political events, including the dissolution of the Yugoslav federation combined with war operations, caused severe economic disruptions dragging the country away from the initially favourable position. While most of the initiated processes, such as privatisation and development of market-oriented institutions, were postponed, a series of new problems arose, including the substantial damages to infrastructure and housing, a

\footnotetext{
${ }^{1}$ Compared to many countries in Central and Eastern Europe.
} 
rapidly growing number of refugees and displaced persons, and a breakdown of trade and capital flows.

The loss of Croatia's markets within the former Yugoslavia and the war-related damages brought about an estimated 40 percent fall in Croatia's total output between 1990 and 1993. This sharp decline together with the increasing expenditures on defence and refugees led to increasing budget deficits, monetary expansion, and accelerating inflation. In October 1993, when the Government launched a stabilisation programme designed to stop hyperinflationary trends and to establish a basis for economic recovery, monthly inflation reached almost 40 percent. $^{2}$ The stabilisation programme succeeded in the reduction of the inflation rate and allowed the build-up of a stable macroeconomic environment that has been maintained ever since.

\subsection{Relations with the EU}

Over the past decade the relations between the EU and Croatia have often been challenged by the political criteria, particularly by disputes over the cooperation with the International Criminal Tribunal for the former Yugoslavia (ICTY) in The Hague. This was the main reason for Croatia's unfavourable status regarding the EU accession in the second half of the 1990s. In spite of being comparably developed as the economies that joined the EU in 2004 and 2007, and the long-term historical ties to Central Europe, the first official document that set an agenda for closer cooperation between Croatia and the EU was signed as late as 2001. This was the Stabilisation and Association Agreement (2001) which the EU designed for the countries in South-Eastern Europe (Albania, Bosnia and Herzegovina, Croatia, FYR Macedonia, Serbia and Montenegro).

These agreements are essentially similar to the Europe Agreements (Association Agreements) implemented in the 1990s for the Central and Eastern European candidate countries. Each agreement is developed specifically for an individual country and sets formal mechanisms and benchmarks to assist a particular country in meeting the EU standards with the aim of formal accession to the EU. As was the case with Europe Agreements, Stabilisation and Association Agreements are accompanied by trade measures and financial assistance by the EU.

The Stabilisation and Association Agreement between the EU and Croatia entered into force on February 1st, 2005 (EC, 2006b). However, from January 2002 until the entry into force, an Interim Agreement (2001) on trade and trade-related matters was applied with the objective of gradually establishing a free trade area over a period of six years. The trade provisions were asymmetrically set in favour of Croatia, meaning that the EU granted Croatia unlimited free access to its own market for almost all products. With respect to the access of EU products to the Croatian market, the Interim Agreement

${ }^{2}$ On economic developments in Croatia during the 1990s and the stabilisation programme introduced in 1993 see more in Anušić et al. (1995). 
included important concessions, with a progressive opening of the Croatian market. In particular, the total duty elimination for industrial products was planned over the six year period (by the beginning of 2007) with the reduction of each duty to $60-70$ percent of the basic duty on the entry into force of the Agreement. As for the agricultural products, processed agricultural products and fisheries products, either full liberalisation or progressive abolishment of customs duties was implemented. About 80 percent of bilateral trade between the EU and Croatia were liberalised upon the entry into force of the Interim Agreement, with a further liberalisation of some 16 percent by 2005 . Full liberalisation of trade was intended to take place six years after the implementation of the Agreement.

In February 2003 Croatia applied for the EU membership and it was granted the candidate status in June 2004. The process of accession negotiations was opened on October 3, 2005. Following the screening process that lasted for roughly a year and involved detailed comparisons between the Croatian legislation and the acquis communautaire, the negotiations started. They were opened with the chapters on science and research, and education and culture, which were temporarily closed in 2006. Out of the remaining 33 chapters, the negotiations on additional 11 chapters have been opened by mid-2007. Although the process seems rather slow compared to the initial expectations, the Croatian Government still declares 2009 as a year in which full accession could be achieved (MFAEI, 2007).

\subsection{Economic Profile}

This subsection compares the Croatian economic structure with those of EU-15 (15 member states before May 2004), NMS-10 (10 countries which acceded in May 2004), EU25 (=EU-15 + NMS-10) as well as for the recent new EU member states, Bulgaria and Romania, and another candidate country, Turkey.

\subsubsection{Key Economic Indicators}

Croatia is a small economy with a population of 4.4 million people and GDP that amounted to $€ 31$ billion in 2005 at current prices. The Croatian economy has performed quite well during the past decade with GDP rising over 40 percent in the period 19962005, while during the period 2001-05 the GDP growth rate was 4.7 percent. As a consequence, the income gap with the EU is decreasing. GDP per capita was nearly $€ 7,000$ in 2005. In purchasing power terms (PPS) this equals 44 percent of the EU-15 average and 48 percent of the EU-25 average. As is shown in Table 2.1, Croatian GDP per capita in PPS equals 80 percent of that in NMS-10, while it is about 30 percent higher than in Bulgaria and Romania, and about 40 percent compared to Turkey. The small population size as well as the output size of the Croatian economy suggest that, by its accession, the EU-25 population would rise by merely 1 percent and the total output would be enlarged by 0.3 percent. 


\begin{tabular}{|l|r|r|r|r|}
\hline Table 2.1 Key Economic Indicators for Croatia in 2005 (compared with other regions and \\
countries)
\end{tabular}

Source: Eurostat (2007).

\subsubsection{Regional Disparities}

As Table 2.2 shows, there are rather considerable welfare differences among the Croatian regions. A large part of economic activity is concentrated in the capital region of Zagreb, resulting in the highest per capita GDP in the country, which is almost 50 percent above the Croatian average. At the same time per capita GDP of the Zagreb region more than doubles that of Eastern Croatia.

The structure of the economy in the most developed regions (Zagreb region and Adriatic North) is characterised by a high share of services. In recent years, the coastal regions, Adriatic North and Adriatic South, have experienced a strong growth of gross value added in tourism. Central Croatia and, in particular, Eastern Croatia have a quite unfavourable economic structure, with a relatively large share of agriculture. Agriculture constitutes 19-20 percent of total employment in the Central and Eastern regions compared to only 4-5 percent in the rest of the country. In addition, these two regions have been the most affected by the war and still suffer from war-related damages.

Table 2.2 Regional Disparities in Croatia

\begin{tabular}{|l|c|c|c|c|}
\hline & $\begin{array}{c}\text { Population } \\
\text { (thousands) }\end{array}$ & $\begin{array}{c}\text { GDP per capita (in \% } \\
\text { of Croatian average) }\end{array}$ & $\begin{array}{c}\text { Employment } \\
\text { rate in \% }\end{array}$ & $\begin{array}{c}\text { Unemployment rate } \\
\text { in \% }\end{array}$ \\
\hline Period & 2003 & 2003 & $2002-04$ & $2002-04$ \\
\hline Zagreb region & 1096 & 148.9 & 55.9 & 11.8 \\
\hline Central Croatia & 1018 & 81.9 & 60.8 & 11.5 \\
\hline Adriatic North & 567 & 123.8 & 58.5 & 9.9 \\
\hline Adriatic South & 874 & 77.3 & 48.9 & 20.2 \\
\hline Eastern Croatia & 885 & 67.4 & 47.9 & 19.9 \\
\hline Croatia & 4440 & 100.0 & 54.5 & 14.5 \\
\hline
\end{tabular}

Note: Employment and unemployment rate according to the Labour Force Survey (average 2002-04).

Source: World Bank (2006). 


\subsubsection{Trade Relations}

In spite of a rather strong economic growth in recent years, Croatia's export performance has been perceived as disappointing. That primarily applies to the goods exports: as a share of GDP, it equalled 23 percent in 2005. Compared to the other countries and regions shown in Table 2.3 this is rather low. As opposed to Turkey, the small size of the Croatian economy should imply much higher openness of the economy. Nevertheless, due to high exports of services (tourism), Croatian exports is close to 50 percent as share of GDP if both goods and services are taken into account. That is slightly lower than in the case of new EU member states in Central and Eastern Europe, but substantially higher than in the case of Romania and Turkey.

In 2005, the share of EU-15 goods exports to Croatia amounted to a negligible 0.3 percent, while close to half of Croatia's goods exports went to the markets of EU-15. Italy and Germany, with 21 and 11 percent of total goods exports respectively, are the leading trade partners. When EU-25 is considered, the share of Croatian exports rises to 62 percent of total goods exports.

\begin{tabular}{|l|c|c|c|c|c|}
\hline Table 2.3 Trade Openness in 2005 \\
\hline & $\begin{array}{c}\text { Exports of } \\
\text { goods and } \\
\text { services } \\
\text { (\% of GDP) }\end{array}$ & $\begin{array}{c}\text { Exports of } \\
\text { goods } \\
\text { (\% of GDP) }\end{array}$ & $\begin{array}{c}\text { Share of exports } \\
\text { to Croatia (\% of } \\
\text { total goods } \\
\text { exports) }\end{array}$ & $\begin{array}{c}\text { Share of exports } \\
\text { to EU-15 (\% of } \\
\text { total goods } \\
\text { exports) }\end{array}$ & $\begin{array}{c}\text { Share of exports } \\
\text { to EU-25 (\% of } \\
\text { total goods } \\
\text { exports) }\end{array}$ \\
\hline EU-25 & 37.0 & 29.4 & 0.4 & & \\
\hline EU-15 & 36.4 & 28.9 & 0.3 & & \\
\hline NMS-10 & 54.7 & 44.4 & 1.3 & & \\
\hline Bulgaria & 60.1 & 44.0 & 1.1 & 52.1 & 56.4 \\
\hline Romania & 33.2 & 28.1 & 1.0 & 60.7 & 69.4 \\
\hline Croatia & 49.3 & 22.8 & - & 48.0 & 61.9 \\
\hline Turkey & 28.6 & 20.3 & 0.3 & 54.3 & 57.1 \\
\hline
\end{tabular}

Note: In case of EU-15 and EU-25, exports refer to intra and extra exports. Source: Eurostat (2007) and CBS (2006a).

A substantial liberalisation of trade took place in Croatia since the accession to the WTO and the implementation of trade provisions defined in the Stabilisation and Association Agreement with the EU in 2001. In addition, Croatia has arrangements on free trade zones with a number of neighbouring countries. While the share of total exports in GDP remained almost unchanged in the 2000s, the share of imports increased from 52 percent in 2001 to roughly 56 percent in 2005. In that period, the current account deficit averaged 6 percent of GDP, indicating increasing external vulnerabilities. 


\subsubsection{Sectoral Structure}

Table 2.4 indicates the total value added across fifteen different sectors based on 2001 data originating from the GTAP database, version 6. The Croatian economy has a relatively large share of value added in service sectors. Due to favourable natural resources, that include an extensive coastline, tourism is one of the most important sectors of the Croatian economy. However, according to the classification used in the GTAP database, tourism is not treated separately but is mainly part of both Trade services and Transport services. Specifically, Trade services include wholesale and retail trade as well as hotels and restaurants and are, according to the share in the total value added, as important in Croatia as in the EU-15 and NMS-10 but significantly more important than in Romania and Bulgaria. As for Transport services, they are relatively more important in Croatia than in the other economies. Altogether, the share of value added in services is about 65 percent.

Table 2.4 Value-added Across Sectors in \% of Total Value Added, 2001

\begin{tabular}{|l|r|r|r|r|r|r|}
\hline & Croatia & Bulgaria & Romania & NMS-10 & \multicolumn{1}{c|}{ Turkey } & EU-15 \\
\hline Agriculture & 8.3 & 26.7 & 17.2 & 5.3 & 12.4 & 2.2 \\
\hline Energy & 0.3 & 6.9 & 6.2 & 3.3 & 3.9 & 2.0 \\
\hline Food processing & 4.0 & 9.2 & 12.7 & 5.4 & 5.8 & 2.8 \\
\hline Textiles & 0.3 & 3.1 & 1.5 & 1.1 & 1.7 & 0.5 \\
\hline Wearing apparel & 1.0 & 0.8 & 4.6 & 1.4 & 1.0 & 0.4 \\
\hline Chemicals and minerals & 3.3 & 7.1 & 4.0 & 5.0 & 3.4 & 4.2 \\
\hline Other manufacturing & 3.9 & 2.7 & 4.5 & 4.9 & 2.1 & 3.6 \\
\hline Metals & 0.2 & 2.5 & 1.1 & 2.0 & 1.5 & 0.9 \\
\hline Machinery and equipment & 5.2 & 4.2 & 4.9 & 8.3 & 3.7 & 7.1 \\
\hline Transport equipment & 0.8 & 0.5 & 2.3 & 2.4 & 1.4 & 2.4 \\
\hline Transport services & 10.4 & 5.8 & 7.1 & 5.5 & 12.1 & 4.6 \\
\hline Trade services & 11.8 & 4.0 & 6.1 & 12.2 & 20.6 & 12.7 \\
\hline Business services & 15.7 & 20.4 & 17.2 & 16.9 & 7.1 & 18.7 \\
\hline Other services & 26.9 & 3.8 & 4.5 & 19.7 & 18.0 & 32.0 \\
\hline Construction & 8.0 & 2.3 & 6.0 & 6.7 & 5.2 & 5.9 \\
\hline
\end{tabular}

Source: Dimaranan and McDougall (2004) and authors' calculations.

The agricultural sector comprises 8.3 percent of the total value added, which is a large share compared to EU-15 but much lower than in Bulgaria, Romania and Turkey. The contribution of most manufacturing sectors is rather low with only Machinery and equipment, Food processing, Chemicals and minerals and Other manufacturing having a more important role in generating value added.

It is worth noting that the Croatian statistical sources suggest some differences regarding the importance of certain sectors. This primarily refers to the energy sector, which contributes with 6 percent to the total valued added according to the Croatian sources (as opposed to the GTAP data that suggest 0.3 percent). The value-added share of 
construction is, according to the Croatian sources, about 3 percentage points lower than according to the GTAP data (CBS, 2006a).

\subsubsection{Export Specialisation}

Table 2.5 shows the share of exports in total production as well as the share of exports of the fifteen sectors in total exports. Services are highly important for the Croatian exports and comprise more than 45 percent of total exports. World-wide, this is on average 20 percent of all trade, and for the EU it is slightly larger, as can be deducted from Table 2.3. In addition, manufacturing sectors such as Textiles, Wearing apparel, Metals and Transport equipment show a high degree of openness. However, the share of these sectors in total exports is relatively low.

\begin{tabular}{|l|c|c|}
\hline \multicolumn{4}{|l|}{ Table 2.5 Exports Share and Openness by Sector in Croatia, 2001 } \\
\hline Agriculture & Exports as \% of production & Exports as \% of total exports \\
\hline Energy & 7.1 & 2.4 \\
\hline Food processing & 8.0 & 0.7 \\
\hline Textiles & 14.9 & 4.6 \\
\hline Wearing apparel & 88.6 & 2.0 \\
\hline Chemicals and minerals & 79.3 & 3.2 \\
\hline Other manufacturing & 45.9 & 10.0 \\
\hline Metals & 34.0 & 8.0 \\
\hline Machinery and equipment & 57.9 & 2.1 \\
\hline Transport equipment & 36.8 & 11.5 \\
\hline Transport services & 75.8 & 7.9 \\
\hline Trade services & 33.1 & 17.9 \\
\hline Business services & 7.2 & 3.6 \\
\hline Other services & 35.6 & 21.1 \\
\hline Construction & 5.3 & 2.9 \\
\hline
\end{tabular}

Source: Dimaranan and McDougall (2004) and authors' calculations.

\subsubsection{Foreign Direct Investment}

FDI inflows into Croatia have been rather high by international comparison. Expressed in per capita terms, cumulative FDI into Croatia amounted to $€ 2,800$ per capita at the end of 2005 or some 40 percent of GDP. According to these indicators, Croatia belongs to the most attractive locations for foreign investments compared to the new EU member states in Central and Eastern Europe. ${ }^{3}$ However, while in the majority of Central and Eastern European countries foreign investors have been attracted by low labour costs, most of the investors in Croatia came either as strategic investors during the privatisation process or in order to increase their market share. Consequently, most of the foreign

\footnotetext{
${ }^{3}$ See Lejour (2007) for an overview of FDI to Central and Eastern European countries based on UNCTAD (2006) data.
} 
investments took place in already existing capacities. Investments in new capacity, socalled greenfield investments, have been scarce. Most of the foreign investments, almost 60 percent, took place in the service sector (particularly in the banking sector and telecommunications) and much less in the manufacturing sectors. As a result, FDI contributed much to the restructuring in financial services and trade, but had little impact on manufacturing in Croatia.

\begin{tabular}{|c|r|r|r|r|r|}
\hline \multicolumn{7}{|c|}{ Table 2.6 Stock of Foreign Direct Investment in Croatia, 2005 } \\
\hline $\begin{array}{c}\text { Stock of FDI } \\
\text { (in million } € \text { ) }\end{array}$ & $\begin{array}{c}\text { Stock of FDI } \\
\text { as a \% of GDP }\end{array}$ & $\begin{array}{c}\text { Share of FDI } \\
\text { from EU-15 (\%) }\end{array}$ & $\begin{array}{c}\text { Share of FDI } \\
\text { from NMS-10 (\%) }\end{array}$ & $\begin{array}{c}\text { Share of FDI } \\
\text { in services (\%) }\end{array}$ & $\begin{array}{c}\text { Share of FDI in } \\
\text { manufacturing (\%) }\end{array}$ \\
\hline 12242 & 39.6 & 73.3 & 12.1 & 57.9 & 27.4 \\
\hline
\end{tabular}

Source: Croatian National Bank (2007).

\section{Croatia's Accession to the EU}

\subsection{Croatia's Development without Accession}

How would the Croatian economy develop over the next twenty years if the country would not accede to the EU? One could imagine rather different scenarios. For example, Croatia could further integrate economically with the EU without becoming a full member. In that case, the current free trade area might be further deepened or Croatia might become a part of the internal market as some other non-member European countries, such as Norway and Iceland. This uncertainty about the future developments in the absence of accession to the EU renders it difficult to assess the economic implications of the accession itself. In model simulations, the usual approach is to develop a so-called baseline scenario in which the current situation is extrapolated into the future. Thus, the baseline neither assumes a tendency towards disintegration nor a tendency towards more integration. The impact of the accession to the $\mathrm{EU}$ is then determined by comparing the economic outcomes of a scenario with accession to the baseline.

In the next section, we follow this approach by simulating the economic implications of the Croatian accession with the CGE model. Thus, we develop a baseline until 2025 in which the relationship between Croatia and the EU remains as it is today, i.e. a free trade area in industrial products and a majority of agricultural products, a limited degree of integration with respect to the internal market, but neither full EU membership nor further integration in other respects. In the baseline, economic growth exceeds that in the EU due to a catching up process. In particular, the baseline assumes a real GDP growth rate of 4.3 percent per year in Croatia, which equals the average growth rate between 1996 and 2005. GDP per capita growth is slightly higher, because of a gradually shrinking population of about 0.2 percent annually according to the United Nations (2004). In the New Member States (NMS) growth is about 4 percent per year. GDP in EU-15 is assumed to grow at 2.2 percent per year during the coming decades. We do not include substantial reforms in the Croatian economic policy as compared to today's situation. 
We determine first the long-term economic outcomes in the baseline scenario and then compare them with the outcomes in the scenario with Croatia's accession to the EU. Thereby, we assume that Croatia becomes an EU member in 2009, which is the target date set by the Croatian Government. This may seem somewhat too optimistic because only two of the 35 negotiating chapters have been closed so far (EC, 2006a). The exact date, however, has no significant impact on the long-term simulation outcomes.

An important question is: what effects do we attribute to Croatia's accession to the EU? In the next two subsections, we discuss two changes that are induced by Croatia's accession to the EU. These are accession to the internal European market and an improvement of Croatia's institutions in response to the EU-membership. ${ }^{4}$

\subsection{Accession to the Internal Market}

A major economic aspect of Croatia's accession to the EU involves the accession to the internal market. This will affect the economies of Croatia and EU members via trade, FDI, domestic investment, and so on. The focus here is on the trade effects of the internal market accession.

Even when a free trade area between Croatia and the EU already exists, accession to the internal market may increase mutual trade for at least three reasons. First, administrative barriers to trade will be eliminated or at least reduced to the levels comparable to those between the current EU members. Here, one can think of reduced costs of passing the customs at the frontier: less time delays, less formalities, etc. Secondly, accession to the internal market implies a reduction in the technical barriers to trade. The Single Market reduces these technical barriers by means of mutual recognition of different technical regulations, minimum requirements and the harmonisation of rules. Finally, risk and uncertainty will be mitigated by Croatia's accession to the EU. In particular, confidence in Croatia's political and economic stability will rise.

In measuring the economic implications of accession to the internal market, we follow the approach in Lejour et al. (2004). The study shows for the countries from Central and Eastern Europe that the accession to the internal market is a much more important issue than the elimination of bilateral trade tariffs and the introduction of common external tariffs as in a customs union. That conclusion and the existing trade agreements between Croatia and the EU in manufacturing and agriculture suggest that the accession to the internal market is the relevant issue, and not the elimination of the remaining tariffs and the harmonisation of the external tariffs. Lejour et al. (2004) measure the economic consequences of accession in two steps. First, they estimate gravity equations on the industry level for the year 2001. These equations are specified as: ${ }^{5}$

\footnotetext{
${ }^{4}$ Both subsections are based on Lejour and De Mooij (2005).

${ }^{5}$ Note that the composition of sectors in this paper differs from that in Lejour et al. (2004).
} 
$X_{i j s}=\alpha_{s} Z_{i j s}+\beta_{s} D_{i j s}{ }^{E U}$

where $X_{i j s}$ stands for the $\log$ of exports from country $i$ to $j$ in industry $s$. The vector $Z_{i j s}$ contains several explanatory variables, including GDP (per capita) of the exporting and importing countries, the distance between the capitals of countries, a set of dummies and the bilateral import and export tariffs between countries. The vector $\alpha_{s}$ contains the parameters we estimate for each sector. The variable $D^{E U}$ is a dummy that equals unity if $i$ and $j$ are currently members of the EU and zero elsewhere. Our main interest is in the estimated coefficient for the EU-dummy, $D^{E U}$. For each of the 15 sectors the coefficient $\beta_{s}$ is estimated by OLS using a cross-section of 38 countries for 2001 based on the GTAP data (Dimaranan and McDougall, 2004). The estimates for the EU-dummy are reported in the first column of Table 3.1. The estimates for the other coefficients are presented in Lejour and de Mooij (2005).

Table 3.1 reveals that in twelve out of fifteen industries, the dummy has a positive and significant coefficient (at the 10 percent confidence level). Hence, in these sectors, bilateral trade is systematically higher if two countries are both members of the EU. The dummies for Agriculture and Food processing are among the largest. Hence, the internal market in the EU intensifies intra-regional trade in these sectors. For Textiles and Wearing apparel, we also find a high and significant dummy. The dummy for Energy and raw materials is negative, but insignificant. This may be due to oil being intensively traded between EU members and non-members. For Transport equipment and Other services, we also find an insignificant EU-dummy. This suggests that, in these sectors, trade among the EU members is not significantly more intense compared to two otherwise equivalent countries that are not EU members. The insignificant dummies may either refer to industries where the internal market has not yet progressed much or where technical barriers to trade are unimportant.

The second column of Table 3.1 shows the trade increase that corresponds to the estimated EU-dummy. In particular, we assume that the EU-membership implies that the dummy would change from zero to one for bilateral trade patterns between the EU and Croatia. Thus, potential trade can be calculated as $\exp \left(\beta_{s}\right)$, where $\beta_{s}$ denotes the estimated coefficient for the EU-dummy in Equation (1). To illustrate, the coefficient for the EUdummy in Wearing apparel is equal to 0.49 so that the potential trade is $\exp (0.49)=1.64$. This implies that trade after accession to the EU is 1.64 times as large as the actual trade between Croatia and the EU members. The potential trade increase is therefore 64 percent of the current trade volume. For industries with an insignificant dummy (not significant at the 10 percent level), we assume that the dummy variable is zero. Hence, accession to the internal market is assumed to have no impact on trade. Overall, estimates suggest that weighed average of the trade increases 34 percent. Hence, aggregate trade with the EU can rise by this percentage if Croatia would be a full member of the EU, as compared to the situation in 2001. Flam (2003) arrives at an estimate of 45 percent by estimating a macro gravity equation on the basis of a panel of 15 countries and for the period 1990-2000. Baldwin et al. (1997) as well as Brenton and Gros (1997) 
find an increase in bilateral trade between the EU members of about 30 percent and Fidrmuc and Fidrmuc (2003) report a 40 percent increase also using macro data. We adopt a cross-section approach, using bilateral trade between 38 countries for 2001. Note that this outcome assumes that Croatia is an average country in the sample of 38 countries. Differences in bilateral trade relations and in the structure of the economy could affect the outcomes substantially.

\begin{tabular}{|l|c|c|c|}
\hline Table 3.1 Trade Increase and Corresponding NTB per Sector on the Basis of EU-dummy \\
\hline & EU-dummy & Trade increase in \% & Non-tariff barrier \\
\hline Agriculture & $0.75^{* *}$ & 112 & 16 \\
\hline Business services (incl. Communication) & $0.56^{* *}$ & 75 & 17 \\
\hline Construction & $0.23^{*}$ & 27 & 8 \\
\hline Chemicals and minerals & $0.34^{* *}$ & 41 & 7 \\
\hline Energy and raw materials & -0.04 & 0 & 0 \\
\hline Food processing & $0.81^{* *}$ & 124 & 17 \\
\hline Machinery and electronic equipment & $0.16^{*}$ & 18 & 4 \\
\hline Metals & $0.20^{*}$ & 22 & 4 \\
\hline Other manufacturing & $0.25^{* *}$ & 28 & 5 \\
\hline Other services & -0.10 & 0 & 0 \\
\hline Textiles & $0.58^{* *}$ & 78 & 12 \\
\hline Transport services & $0.14^{*}$ & 15 & 3 \\
\hline Trade services & $0.81^{* *}$ & 124 & 24 \\
\hline Transport equipment & 0.05 & 0 & 0 \\
\hline Wearing apparel & $0.49^{* *}$ & 64 & 10 \\
\hline & & 34 & \\
\hline All sectors & $0.29^{* *}$ & & \\
\hline
\end{tabular}

Note: ** Significant at the 5 percent level; * Significant at the 10 percent level. Source: Lejour and de Mooij (2005).

After having determined the potential trade increase per sector, the next step is to translate this into non-tariff barriers (NTBs). These are presented in the third column of Table 3.1. Following the methodology of Lejour et al. (2004), we translate the potential trade increase per sector into a Samuelsonian iceberg trade-cost equivalent. We refer to this as a non-tariff barrier. In particular, we recalibrate the Armington demand functions in the model (i.e. the preference parameters in the utility functions) such that these reproduce the original trade data (while NTBs are incorporated). Abolishing the NTBs for all sectors in our CGE model (which is discussed in more detail in Section 4), we arrive at the trade levels that correspond to the predictions in the second column of Table 3.1. Lejour et al. (2004) describe this procedure in more detail. The estimated NTBs depend largely on the sector-specific Armington elasticities in the model, which measure the sensitivity of exports with respect to trade costs. The NTBs in the last column of Table 3.1 can be interpreted as the trade costs associated with the non-membership of Croatia in the internal market. 
We call these trade costs NTBs, and map them into one NTB indicator for technical reasons. However, in reality, these trade costs are quite diverse. Simplified customs procedures facilitate trade and lower costs. Standardising technical regulation is called a technical barrier to trade, which could lower costs but also eliminate rents. In the simulation model, these trade costs are lumped together in one NTB which creates rents.

\subsection{Improving Institutions in Croatia}

Lejour and de Mooij (2005) argue in their study on the effects of the possible Turkish EU-membership that accession to the EU may work as a catalyst for institutional reforms. For instance, by becoming an EU-member, the candidate country has to conform to all EU legislation and enforcement by the European Court of Justice. Moreover, via the method of open coordination, economic policies of an individual member country are regularly assessed by the European Commission as well as other member states. EU-membership can thus trigger institutional reforms in Croatia and reduce bureaucracy, lack of transparency on government regulation and policy implementation. Today, inefficient institutions and non-transparent practices hinder economic transactions substantially. As a result, Croatia ranks low on the Transparency Index which measures corruption perception, as can be seen from Table 3.2. The index represents the degree of corruption perceived by professionals, academics and risk analysts derived from surveys and is constructed by Transparency International. The assessment is between 0 and 10. In 2006, Haiti scored lowest with an index of 1.8 and Finland, Iceland and New Zealand highest with 9.6. For the new member states like Estonia and Slovenia the index exceeds 6, comparable to some old EU member states. The other NMS score lower, but Hungary, the Czech Republic and Poland score higher than the candidate countries.

Improvements in institutions and transparency may benefit the economic development of Croatia by improving its competitive position. To illustrate, De Groot et al. (2004) estimate this impact for a wide set of countries, using a gravity estimation approach. They show that a similar law or regulatory framework as in the EU could increase bilateral trade between 12 percent and 18 percent. Better quality institutions and less corruption would increase trade by 17 percent to 27 percent. Considering FDI flows toward South-Eastern Europe, the OECD (2006) pleas for regulatory reform and enforcement of anti-corruption measures in South-Eastern Europe. Enforcement is a major issue here, as is the improvement of tax administration. Although we cannot explicitly attribute the extent to which the EU-membership will actually improve institutions in Croatia, it is clear that these have to be reformed in order to conform to the internal EU market and the acquis communautaire. It can not be excluded that Croatia would reform its institutions without becoming an EU member, but the possible EUmembership will undoubtedly be an extra stimulus to conduct these reforms. 
By way of illustrating the importance of national institutional reforms, we have assessed the importance of institutions for trade relations. In particular, Lejour and De Mooij (2005) have re-estimated the gravity equation on aggregate trade of the previous section by including a multiplicative construct of the Transparency International Corruption Perceptions Index for the exporting and importing country in Equation (1). The coefficient for this index in the gravity equation measures the systematic impact of corruption on the intensity of bilateral trade between countries. ${ }^{6}$ To gauge the quantitative importance of institutions for trade, we did the following experiment. Suppose that, by improving institutions and obtaining more discipline within bureaucracies, the EU-membership of Croatia would raise the TI Corruption Perceptions Index to a level comparable with Portugal, i.e. Croatia would advance from place 69 with an index of 3.4 to place 26 with a value of 6.6. By doing so, we find that Croatia's aggregate trade would rise by 56 percent. Compared to the EU-dummy for the internal market (which induces a rise in bilateral trade between Croatia and the EU by 34 percent, suggesting an increase in aggregate trade of around 23 percent since the EU share in Croatian trade is about 65 percent), the impact of less corruption would be much bigger. If the EU-membership would indeed work as a catalyst for institutional reforms, this process has potentially important economic implications for Croatia.

However, such a change in institutional settings takes normally decades. In most countries, institutions change slowly. The trade effects are thus big, but the institutional change as well. It is also possible that the EU-membership is less successful as a catalyst for institutional reforms. Assume that Croatia only rises to place 41 with an index of 5.2, a level comparable to that of Hungary. In that case, the aggregate trade of Croatia would still rise by 28 percent.

Table 3.2 Transparency International Perceptions Corruption Index 2006 for a Selection of Countries, Including Their Ranking

\begin{tabular}{|l|c|l|c|}
\hline \multicolumn{1}{|c|}{ Ranking of countries } & $\begin{array}{c}\text { Corruption } \\
\text { Perceptions Index } \\
\mathbf{2 0 0 6}^{*}\end{array}$ & Ranking of countries & $\begin{array}{c}\text { Corruption } \\
\text { Perceptions Index } \\
\text { 2006* }\end{array}$ \\
\hline 1 Finland/Iceland/New Zealand & 9.6 & 41 Hungary & 5.2 \\
\hline 4 Denmark & 9.5 & 54 Greece & 4.4 \\
\hline 9 the Netherlands/Australia & 8.7 & 60 Turkey & 3.8 \\
\hline 11 UK/Luxembourg/Austria & 8.6 & 64 Croatia & 3.4 \\
\hline 16 Germany & 8.0 & 90 Serbia/Gabon/Surinam & 3.0 \\
\hline 26 Portugal/Macao & 6.6 & 163 Haiti & 1.8 \\
\hline 28 Slovenia & 6.4 & & \\
\hline
\end{tabular}

Note: "Degree of corruption perceived by business people, academics and risk analysts derived from surveys. The assessment is between 0 (bighly corrupt) and 10 (bighly clean).

Source: bttp://wrewe.transparency.org/.

\footnotetext{
${ }^{6}$ The coefficient for the EU-dummy, measuring the impact of the internal market on trade intensities, does not significantly change if we add the TI index. Lejour and De Mooij (2005) also estimated the gravity equation with an alternative index, the so-called Heritage index, measuring the degree of economic freedom. When using this index, the trade increase is of the similar magnitude as with the TI index.
} 
As we did for the trade effect of the internal market, we translate the trade increase according to the gravity equation technically into an NTB associated with corruption. We then follow the same procedure as in Section 3.2, i.e. we will simulate the gradual removal of the NTB in Section 4, reflecting a gradual improvement in the quality of institutions in Croatia. ${ }^{7}$ It could also be the case that improving institutions affects the Croatian economy directly. Markets become more transparent and function more smoothly. Consequently, production and consumption increase directly without more trade. However, we do not take account of this effect in our analysis.

\subsection{Other Issues}

The EU budget redistributes funds. Contributions are more or less proportional to the countries' GNP. The expenditures by the EU are primarily directed to the Common Agricultural Policy (CAP) and Cohesion Policy, although the budget for these policies is sometimes heavily disputed. Especially the latter expenditure category is geared towards poor countries and regions.

Being a relatively poor country with a relatively large agricultural sector (compared to the EU average), Croatia would probably be eligible for a substantial net inflow of funds from the EU budget. For instance, most Croatian regions would become eligible for the structural convergence (previously Objective 1) support under the current rules. ${ }^{8}$ Although these transfers are capped at a maximum of 4 percent of a region's GDP, the total amount of funds to Croatia may run up to about $€ 1$ billion per year. This may encourage economic growth. The meta analysis of Ederveen et al. (2002) on the growth elasticity of Structural Funds reveals that the potential growth effect of Structural funds that are equal to 4 percent of GDP may be 0.7 percent per year. This, however, assumes that funds are spent appropriately on public investment projects with a high rate of return. ${ }^{9}$

Yet, the rules regarding the allocation of EU funds are unlikely to remain unchanged. The budget will be reviewed in 2008. As it is difficult to predict what these reforms will look like, we do not attempt to address this issue any further. The financing and expenditures of the EU funds are thus not incorporated in the simulations of Section 4.

The free movement of labour is a widely debated topic since the EU included many countries with relatively low income levels in 2004 and 2007. In particular, the massive influx of Polish workers in several EU countries and the expected inflow of Turkish

\footnotetext{
${ }^{7}$ Because we do not have information on the effect of institutional changes on sectoral trade patterns, we assume that trade is affected equivalently in all sectors.

${ }^{8}$ Because of the relatively high incomes in the Zagreb region (see Table 2.2), it is possible that regional income exceeds the qualification criteria of 75 percent of the EU average income at the time of accession.

${ }^{9}$ This figure is based on an ex-ante analysis of the growth effect of Structural funds, using simulation models. Ex-post evaluations, however, suggest zero elasticity on average. Hence, there is substantial room for improvement in the effectiveness of structural funds in terms of stimulating convergence. See Ederveen et al. (2002).
} 
workers, if Turkey joins the EU, cause many concerns. With respect to the possible EUmembership of Croatia, migration is less relevant. Croatia is a small country compared to the acceded countries in Central and Eastern Europe and Turkey. Even if 3 to 4 percent of the Croatian population would migrate to the current member states, the effects on the EU are modest. The EU population will increase by less than 0.1 percent and the economic effects will be even smaller. Moreover, the number of expected migrants is probably smaller than in the case of Bulgaria, Romania and Turkey, because income per capita in Croatia is higher than in these countries. The Croatian CBS (2006b) even expects a net migration inflow. For these reasons we do not analyse the free movement of labour.

A large part of Croatia's exports are driven by the tourist sector. Consequently, a substantial portion of economic growth in Croatia is caused by the upsurge in tourism. As explained in Section 2, tourism is not a sector in the policy reform analysis due to the classification of the sectoral data used in this study. It is difficult to address the consequences of EU-membership for tourism. It would improve the image of Croatia and thereby its attractiveness as a tourist destination. In addition, EU-membership could stimulate inward FDI in transport, hotels and restaurants. It could also be a starter for other developments, like the inclusion of Croatia in the Schengen area and the acceptance of the euro. These future developments could facilitate tourism but are outside the scope of this analysis.

\section{The Economic Impact of Croatia's Accession to the EU}

This section explores the economic implications of Croatia's accession to the internal market and a potential improvement in national institutions. We do this by simulating two experiments with the WorldScan model. For each of these experiments we discuss the macroeconomic effects and sectoral implications. The accession to the internal market is simulated by eliminating export subsidies, implementing the common external tariff vis à vis third countries and by eliminating non-tariff barriers, which reflect among other things, technical barriers to trade as additional benefits of the internal market. The improvement in the institutional setting is simulated by the elimination of non-tariff barriers, which reflects on improvement in the corruption index that serves as a proxy for the quality of institutions. Before elaborating on the results of these two simulations, we first give a brief sketch of the model structure.

\subsection{The WorldScan Model}

WorldScan is a computable general equilibrium model for the world economy (Lejour et al., 2006a). The model is calibrated on the basis of the GTAP database, version 6 (Dimaranan and McDougall, 2004) with 2001 as the base year. The database allows us to distinguish between a large number of regions and sectors. In particular, the EU is 
divided into six regions: Germany, France, UK, the Netherlands, Italy, and the Rest of the EU. The countries that acceded to the EU in 2004 and 2007 (NMS-10, Bulgaria and Romania) are referred to as the NMS-12. Candidate countries, Croatia and Turkey, are distinguished separately. The rest of the world economy is divided further into four other regions, namely, the former Soviet Union, the Rest of the OECD, Middle East and North Africa and Rest of the World. For each region, we distinguish fifteen sectors. These consist of agriculture, raw materials and energy, eight manufacturing sectors and five service sectors.

The heart of the WorldScan model relies on neoclassical theories of growth and international trade. Sectoral production technologies are modelled as nested CES functions. One of the nests is value-added. The production of value-added is modelled by means of a Cobb-Douglas technology with low and high-skilled labour and capital as inputs. In principle, there are fifteen intermediate inputs. However, only few intermediate inputs are important in the production process for most industries.

With respect to trade, WorldScan adopts an Armington specification, explaining two-way trade between regions and allowing market power of each region. The demand elasticity for manufacturing industries is set at 5.6. For services industries the elasticity is set at 4.0. On the capital market, WorldScan assumes imperfect capital mobility across borders. In particular, capital that is abundant in one region (and thus is relatively inexpensive) is invested in another region in which capital is scarce (capital is expensive). Due to barriers in investing abroad interest rate differentials are reduced but not eliminated. Consumption patterns may differ across countries and depend on per capita income. We assume the labour markets for low- and high-skilled workers clear. In the baseline, labour does not migrate.

Although WorldScan is rather comprehensive in describing trade relations and contains a detailed description of countries and sectors, it does not capture some economic mechanisms that are potentially important in the light of EU enlargement. For instance, this version of the model does not include economies of scale. Economic integration may thus yield additional efficiency gains through better exploiting these potential scale effects. Moreover, this version of WorldScan does not capture technology and knowledge spillovers, associated with the increasing trade intensity between Croatia and the EU. Such spillovers, as well as other dynamic gains from economic integration, may yield additional benefits. They are, however, difficult to quantify and therefore not captured in the model. The simulations thus only capture the static allocative efficiency gains from EU accession.

As discussed in Section 3.1, the baseline scenario of WorldScan includes developments that can be foreseen, such as demographic projections and a gradual catching up process of Croatia, other candidate countries and the new EU members in Central and Eastern Europe. We assess the implications of Croatia's EU-accession by running successively two alternative scenarios in which we impose the removal of non-tariff barriers as a result of 
accession to the internal market and an improvement in the institutions. By comparing the outcomes of these alternative scenarios with the baseline, we obtain the impact of EUmembership on Croatia and the economies of the EU, in particular the new member states. In these experiments, we assume that Croatia enters the EU in 2009. The shocks are implemented gradually and the effects are evaluated in the year 2025.

\subsection{Croatia's Accession to the Internal Market}

We now discuss the simulation results of Croatia's accession to the internal market. In particular, we simulate a gradual abolishment of the NTBs presented in Table 3.1. This removal of NTBs changes relative prices, exerts trade creation and trade diversion, changes the terms-of-trade and affects the incentives to invest.

Except for the elimination of NTBs we also eliminate the EU export subsidies in food products towards Croatia and include changes in import tariffs levied by Croatia in order to comply with the EU external import tariffs. Separate simulations of these last two items reveal that the total effects of the internal market are nearly completely driven by abolishing the NTBs. Therefore, we discuss only the effects caused by eliminating the NTBs.

\subsubsection{Macroeconomic Effects}

Table 4.1 presents the macroeconomic effects of Croatia's accession to the internal market. We see that GDP and consumption in Croatia increase by 1.1 percent and 2.6 percent, respectively. Welfare, measured by the equivalent variation (i.e. a measure for the rise in real private income) increases by $€ 1.1$ billion in constant prices. ${ }^{10}$ For EU-15, the economic effects are negligible. Welfare rises by $€ 0.7$ billion. The NMS-12 countries also experience insignificant impact on GDP, but an increase in welfare of $€ 0.2$ billion.

These effects are the result of two main mechanisms. First, changes in relative prices imply that countries can better exploit their comparative advantages. This causes trade creation, increases production efficiency and raises welfare. At the same time, however, integration with Croatia causes trade diversion, but this effect is very small.

The second effect of Croatia's accession to the EU is a terms-of-trade effect. This effect is not a traditional terms-of-trade effect, but the result of a change in transaction costs, modelled by a change in the Samuelsonian iceberg costs. In particular, we see that Croatia experiences a terms-of-trade gain of 3.3 percent. This is not accompanied by a terms-of-trade loss in other European countries. The reason for the presence of terms-oftrade gains on both sides is that the abolishment of NTBs entails a reduction in real

\footnotetext{
${ }^{10}$ Note that in the GTAP data base (version 6) all prices are expressed in US\$ for the year 2001. We have used the average exchange rate for 2001 to express all monetary values in $€$ (constant prices).
} 
trade costs. As we measure the terms-of-trade as the price of exports relative to imports that holds just outside the domestic border, lower NTBs can raise the price of exports relative to imports in both countries. ${ }^{11}$ A different magnitude in the terms-of-trade effect among countries depends on the trade intensity between that country and Croatia. In particular, the export shares of NMS-12 and EU-15 to Croatia are rather small, while the corresponding share of Croatia's exports to the EU is relatively large. This explains the large terms-of-trade effect for Croatia relative to the other regions.

We can compare the effects in Table 4.1 with those found by Lejour et al. (2004) for the Central and Eastern European countries and by Lejour and de Mooij (2005) for Turkey. These simulations were also performed with the WorldScan model. The comparison reveals that the effects for Turkey are relatively small. Indeed, EU enlargement with the Central and Eastern European countries yields an average increase in GDP by 5.3 percent for the accession countries, while consumption increases by almost 10 percent. For the Turkish accession, the corresponding figures are 0.8 percent and 1.4 percent. For Croatia, the figures are 1.1 percent and 2.6 percent respectively. These results are comparable to those of the Turkish accession. The reason for the differences with Central and Eastern European countries is threefold. ${ }^{12}$ First, we have re-estimated our gravity equations on the basis of data for 2001. The new estimations suggest an aggregate trade increase for the EU-bilateral trade with Croatia and Turkey of 34 percent. This is about one third smaller than the increase of more than 50 percent for the Central and Eastern European countries that was suggested by the previous estimate (which was based on data for 1997). Secondly, Croatia (as also Turkey) specialises in sectors for which we find relatively small effects for the internal market EU-dummy. For instance, we do not obtain a significant NTB for Transport, a sector that is relatively important for the Croatian economy (see Table 2.4). We do have a large NTB in the sector Trade services which is important for Croatia. However, trade in that sector is low, according to Table 2.5, and the trade increase has no substantial effect on production in that sector. Finally, the export increase of Croatia primarily involves sectors with a relatively low productivity, such as Textiles, and Wearing apparel. Although these sectors benefit substantially (see Table 4.2), this does not create big effects on value added and consumption.

Total exports of Croatia rise by 13.9 percent and imports by 15.9 percent. This is less than expected based on the gravity equation. According to the latter method, aggregate trade would rise by about 23 percent. There are several reasons for this difference. First, there is also trade diversion. Increased trade with the EU leads to less trade with other countries. This reduces the increase in total trade. Secondly, Croatia also needs (skilled) labour, capital and intermediate inputs, such as machinery and equipment, for production. These inputs are scarce. This reduces the trade potential.

\footnotetext{
${ }^{11}$ For imports, the price includes cost of freight (the iceberg costs and the c.i.f - inclusive of cost, insurance and freight - that are present in the database) but not import taxes. For exports, the price is f.o.b (free on board) and includes export taxes but excludes the iceberg costs.

${ }^{12}$ In the case of Turkey, the relative low share of EU-trade (about 50 percent of al trade) was also a reason for the modest economic effects. This does not apply to Croatia. About two-thirds of the trade is destined for or comes from the EU. This share is comparable to that of other accession countries.
} 


\begin{tabular}{|l|c|c|c|c|c|}
\hline Table 4.1 Macroeconomic Effects of Croatia's Accession to the Internal Market in 2025 \\
\hline & $\begin{array}{c}\text { Volume of } \\
\text { GDP } \\
\text { (\%) }\end{array}$ & $\begin{array}{c}\text { Volume of } \\
\text { consumption } \\
\text { (\%) }\end{array}$ & $\begin{array}{c}\text { Equivalent } \\
\text { variation } \\
\text { (billion } \boldsymbol{\epsilon})\end{array}$ & $\begin{array}{c}\text { Export volume } \\
\text { (\%) }\end{array}$ & $\begin{array}{c}\text { Terms of } \\
\text { trade } \\
\text { (\%) }\end{array}$ \\
\hline Croatia & 1.1 & 2.6 & 1.1 & 13.9 & 3.3 \\
\hline NMS-12 & 0.0 & 0.0 & 0.2 & 0.1 & 0.0 \\
\hline EU-15 & 0.0 & 0.0 & 0.7 & 0.0 & 0.0 \\
\hline EU-27 & 0.0 & 0.0 & 0.9 & 0.0 & 0.0 \\
\hline
\end{tabular}

Source: WorldScan simulations. The numbers are percentage changes between the policy simulation and the baseline in 2025, except for the equivalent variation which is an absolute difference.

\subsubsection{Sectoral Effects}

To understand the sectoral effects of Croatia's accession to the internal market, two effects in each sector are important. First, an industry where an NTB is abolished faces fiercer price competition on the home market as the relative price of varieties from the EU falls relative to domestic varieties. This causes a shift in consumer demand away from domestic varieties, leading to higher import intensity. The drop in demand for domestically-produced commodities lowers the producer price, which causes a shift in resources away from the sector where the NTB is abolished. The second effect is that the EU lowers its NTBs. This reduces the relative consumer price of Croatia's varieties in the EU, causing a higher demand for these varieties. This exerts an upward pressure on Croatia's producer price, which attracts inputs to this sector.

Increased specialisation is the net effect of these two opposite effects on prices and production in a sector. On balance, a sector is likely to expand if that sector exports a large share of its production towards the EU. If a sector produces primarily for the home market, cheaper varieties from the EU may render the impact on production in that sector negative.

In addition to the two demand effects above, the removal of NTBs also exerts a supply effect. This is because the reduction in real trade costs changes input prices for two reasons. First, lower real trade costs reduce the price of intermediate inputs so that production costs fall. Second, production costs also change by changes in relative factor prices.

How all these forces work out depends on the details of the input-output structure of the economy, comparative advantages and the trade openness of sectors. A CGE model like WorldScan consistently links these elements and shows how the various shocks and mechanisms ultimately affect the output structure. The results are presented in Table 4.2. It reveals that Textiles and Wearing apparel expand the most. This expansion is a result of their strong export orientation and a relatively large NTB that is abolished. However, these sectors only contribute about 5 percent to Croatia's exports and 1.3 percent to value added. The effect of increased access to the EU market dominates the effect of 
cheaper EU products in Croatia. Other sectors in Croatia also gain. In particular, Table 4.2 shows modest increases in the other manufacturing sectors (except Food processing), Trade services and Construction. Production in Business and Other services and Agriculture contract.

\begin{tabular}{|l|c|c|c|}
\hline \multicolumn{4}{|c|}{$\begin{array}{l}\text { Table 4.2 Sectoral Effects of Croatia's Accession to the Internal Market in } 2025 \text { (numbers } \\
\text { are relative changes in production) }\end{array}$} \\
\hline & Croatia & NMS-12 & EU-15 \\
\hline Agriculture & -1.1 & 0.1 & 0.0 \\
\hline Energy & 0.5 & 0.0 & 0.0 \\
\hline Food processing & -3.1 & 0.1 & 0.0 \\
\hline Textiles & 66.4 & -0.1 & 0.1 \\
\hline Wearing apparel & 30.2 & -0.2 & 0.0 \\
\hline Chemicals and minerals & 7 & 0.0 & -0.0 \\
\hline Other manufacturing & 3 & 0.0 & -0.0 \\
\hline Metals & 9.2 & 0.1 & 0.0 \\
\hline Machinery and equipment & 4.6 & 0.0 & 0.0 \\
\hline Transport equipment & 2.7 & 0.0 & 0.0 \\
\hline Transport services & -0.2 & -0.0 & 0.0 \\
\hline Trade services & 1.2 & -0.0 & -0.0 \\
\hline Business services & -1.3 & -0.0 & 0.0 \\
\hline Other services (mainly government) & -1.3 & 0.0 & 0.0 \\
\hline Construction & 0.2 & 0.0 & 0.0 \\
\hline
\end{tabular}

Source: WorldScan simulations. The numbers are percentage changes between the policy simulation and the baseline in 2025.

Expanding Textile and Wearing apparel sectors in Croatia slightly affect the position of these industries in NMS-12. Some workers thus shift from these sectors towards agriculture, food processing and metals, which show a corresponding increase in production.

\subsection{Institutional Reforms in Croatia}

The second effect of Croatia's accession to the EU involves a potential improvement in national institutions. Indeed, to the extent that EU-membership triggers reforms, it can have important implications for Croatia. We simulate institutional reforms by an improvement in Croatia's position towards the level in Portugal. Probably, such a change will take decades because institutions do not change that fast in most countries. On the TI Corruption Perceptions Index, Croatia jumps from place 69 to 26 (from 3.4 to 6.6 points). This implies an improvement in the competitive position of Croatia, as found by the estimates of the gravity equation of Section 3.3: aggregate trade increases by 56 percent. This trade increase only measures the effects of improved institutions and excludes accession to the internal market dealt with in the previous section. Table 4.3 shows the macroeconomic implications of removing the corresponding NTB, which 
measures the trade barrier associated with the poor position of Croatia on the transparency ladder.

\begin{tabular}{|c|c|c|c|c|c|}
\hline \multirow[t]{2}{*}{ Table 4.3} & \multicolumn{5}{|c|}{$\begin{array}{l}\text { Macroeconomic Effects of a Higher TI Corruption Perceptions Index for Croatia in } \\
2025\end{array}$} \\
\hline & $\begin{array}{l}\text { Volume of } \\
\text { GDP } \\
\text { (\%) }\end{array}$ & $\begin{array}{c}\text { Volume of } \\
\text { consumption } \\
\text { (\%) }\end{array}$ & $\begin{array}{l}\text { Equivalent } \\
\text { variation } \\
\text { (billion } € \text { ) }\end{array}$ & $\begin{array}{l}\text { Export volume } \\
\text { (\%) }\end{array}$ & $\begin{array}{l}\text { Terms of } \\
\text { trade } \\
\text { (\%) }\end{array}$ \\
\hline Croatia & 7.8 & 12.9 & 5.6 & 56.9 & 9.9 \\
\hline NMS-12 & 0.0 & 0.1 & 0.4 & 0.4 & 0.1 \\
\hline EU-15 & 0.0 & 0.0 & 1.8 & 0.1 & 0.0 \\
\hline EU-27 & 0.0 & 0.0 & 2.2 & 0.1 & 0.0 \\
\hline
\end{tabular}

Source: WorldScan simulations. The numbers are percentage changes between the policy simulation and the baseline in 2025, except for the equivalent variation which is an absolute difference.

From Table 4.3 we see that an improvement in institutions raises GDP in Croatia by 7.8 percent, while consumption rises by 12.9 percent. Welfare increases by $€ 5.6$ billion in constant prices. The consumption increase is much larger than the GDP increase because the terms-of-trade improve due to reduced NTBs. The reduction of the NTBs as a way to simulate improved institutions is a mechanical exercise, which makes it more difficult to interpret the difference between the consumption and GDP increase.

These macroeconomic effects are substantially larger than the impact of the accession to the internal market. This is because of two reasons. First, the estimated trade impact of the improvement in the TI Corruption Index is bigger than that of the accession to the internal market: the aggregate trade increase is more than three times larger. Second, the improvement in institutions affects all sectors alike, including trade-intensive sectors like Chemicals, Metals, Transport equipment and Machinery and equipment (see Table 4.4) in contrast to the simulation for the internal market where these sectors were only mildly affected.

Other countries are hardly affected by the improvements in Croatia's institutions. Exports from the 12 new member states increase by 0.4 percent. The equivalent variation suggests that the whole EU experiences a welfare gain equivalent to $€ 2.2$ billion in constant prices.

Although the institutional improvement potentially has an important economic impact for Croatia, these gains will only materialise if the accession of Croatia to the EU will indeed induce such improvement. In case the reforms are less fundamental, the Croatian position on the TI Corruption Perceptions Index ladder improves less. To illustrate, if Croatia climbs up to place 42, the level of a new member state, Hungary, aggregate trade will increase by about 28 percent. This is around half of the trade increase if Croatia would move to the 26th position of Portugal. Macroeconomic effects are also about 50 percent smaller. 


\begin{tabular}{|l|r|l|r|}
\hline \multicolumn{4}{|c|}{$\begin{array}{l}\text { Table 4.4 Sectoral Effects of a Higher TI Corruption Perceptions Index for Croatia in } 2025 \\
\text { (numbers are relative changes in production) }\end{array}$} \\
\hline Agriculture & 1.4 & Machinery and equipment & 34.9 \\
\hline Energy & 4.8 & Transport equipment & 48.8 \\
\hline Food processing & 2.2 & Transport services & 11 \\
\hline Textiles & 89.2 & Trade services & 8.6 \\
\hline Wearing apparel & 33.8 & Business services & -3.9 \\
\hline Chemicals and minerals & 37.8 & Other services & -15.6 \\
\hline Other manufacturing & 11 & Construction & 5.2 \\
\hline Metals & 67.2 & & \\
\hline
\end{tabular}

Source: WorldScan simulations. The numbers are relative differences between the policy simulation and the baseline in 2025.

\section{Conclusions}

With the accession of Romania and Bulgaria in 2007, the European Union has expanded towards South-Eastern Europe. Many countries in this region aspire to join the EU. Croatia, Macedonia and Turkey already have the candidate status while Albania, Bosnia and Herzegovina, Serbia, and Montenegro participate, to a different extent, in the Stabilisation and Association Process which provides a legal framework for the relations between the EU and potential members in the period prior to possible accession. These partnerships are often seen as a first step towards closer integration, although these are not a guarantee for full membership. Apart from Turkey, all these countries are small in terms of population and the size of the economy compared to the EU. Therefore, the current study on the economic consequences of the EU-membership of Croatia holds some interesting conclusions which could also be valid for other countries in SouthEastern Europe.

The first main conclusion is that the economy of the EU would be hardly affected. Welfare could increase by $€ 3.1$ billion, or less than 0.1 percent of GDP. This conclusion also holds for other EU candidates or countries that have recently become full members. In fact, studies on the membership effects of the Central and Eastern European countries and Turkey indicate that the effects on the existing EU members are small, but still substantially larger than in the case of Croatia.

The second conclusion is that the economy of the accession country, in this case Croatia, is heavily affected. GDP could increase by about 9 percent and consumption even more if Croatia enters the internal market and improves its institutions towards the level of Portugal. This stimulus is also possible for other countries in South-Eastern Europe given their level of economic development and institutional settings. However, the improvement in institutions has to be interpreted as an upper bound, and is not likely to be met within one or two decades. 
The analysis probably does not present the total effects of accession. First of all, the effects of FDI are not considered in the analysis. EU-membership gives foreign investors confidence, although OECD (2006) shows this has to be accompanied by measures to reduce corruption and to improve the tax administration. Moreover, EU-membership could make Croatia more attractive as a tourist destination. Third, the undertaken type of simulation analysis underestimates the dynamic effects of integration. Increased market entry and improved institutions facilitate competition. Although this process is sometimes painful because the less efficient firms disappear, on average it increases productivity and stimulates innovation. Lejour et al. (2006b) conducted a two-stage econometric analysis to investigate the long-term effects of the EU accession on trade and growth. They also took into account the effects of improved institutions and concluded that for the 12 new EU member states plus Turkey income could increase by about 38 percent on average. However, it will take many decades before an increase of this magnitude will be realised in these countries (at least much longer than the time horizon of this study, 2025). The analysis did not focus on Croatia, but a stimulus of this magnitude could be reached by Croatia. However, one important difference compared with most of the other new member states is the limited size of manufacturing in Croatia. The European experience suggests that promoting competition and raising productivity is easier in manufacturing than in services. Services are relatively important in Croatia which suggests that deregulation and market reform policies in the service sector could be vital to grasp the full economic gains of the possible EU-membership. 


\section{References}

Anušić, Z., Ž. Rohatinski and V. Šonje, eds., 1995, A Road to Low Inflation: Croatia, 19931994, Zagreb: Government of the Republic of Croatia.

Baldwin, R. E., J. F. Francois and R. Portes, 1997, "The Costs and Benefits of Eastern Enlargement: The Impact on the EU and Central Europe", Economic Policy, April, (24), pp. 125-170.

Brenton, P. and D. Gros, 1997, "Trade reorientation and recovery in transition economies”, Oxford Review of Economic Policy, 13(2), pp. 65-76.

Central Bureau of Statistics, 2006a, Statistical Yearbook, Zagreb: Central Bureau of Statistics of the Republic of Croatia, http://www.dzs.hr.

Central Bureau of Statistics, 2006b, Projekcije stanovnistva Republike Hrvatske: 2004.-2051., Zagreb: Central Bureau of Statistics of the Republic of Croatia.

Croatian National Bank, 2007, http://www.hnb.hr.

De Groot, H. L. F., G.-J. Linders, P. Rietveld and U. Subramanian, 2004, "The institutional determinants of bilateral trade patterns”, Kyklos, 57(1), pp. 103-123.

Dimaranan, B. V. and R. A. McDougall, 2004, Global Trade Assistance and Protection: The GTAP 6 data base (pre-release), Centre for Global Trade Analysis, Purdue University.

Ederveen, S., J. Gorter, R. A. de Mooij and R. Nahuis, 2002, Funds and games: the economics of European cohesion policy, CPB Special Publication, The Hague: CPB Netherlands Bureau for Economic Policy Analysis.

EurActiv, 2006, "Croatia wants to join by 2009 despite 'enlargement pause”, http://www.euractiv.com (published: 9 October 2006).

European Commission, 2006a, "Progress report on Croatia", Brussels: European Commission, http://ec.europa.eu/enlargement/key_documents/reports_nov_2006_en.htm.

European Commission, 2006b, "Croatia: EU- Croatia relations", Brussels: European Commission, http://ec.europa.eu/enlargement/croatia/eu_croatia_relations_en.htm.

European Commission, 2006c, "Standard Eurobarometer: National report Croatia", Executive Summary, Brussels: European Commission, http://www.delhrv.ec.europa.eu/en/static/view/id/317.

Eurostat, 2007, http://ec.europa.eu/eurostat.

Fidrmuc, J. and J. Fidrmuc, 2003, "Disintegration and trade", Revieze of International Economics, 11(5), pp. 811-829.

Flam, H., 2003, "Turkey and the EU: Politics and economics of accession", CESifo Working Paper, No. 893, Munich: CESIfo. 
Interim Agreement, 2001,

http://www.mvpei.hr/ei/download/2001/09/12/Interim_Agreement.pdf.

Lejour, A. M., 2007, "FDI in services: recent developments and prospects in Europe" in K. Liebscher, J. Christl, P. Mooslechner, D. Ritzberger-Grūnwald, eds., Foreign Direct Investment in Europe, Cheltenham: Edward Elgar, pp. 175-189.

Lejour, A. M. and R. A. de Mooij, 2005, “Turkish Delight: Does Turkey’s Accession to the EU Bring Economic Benefits?”, Kyklos, 58(1), pp. 87-120.

Lejour, A. M., R. A. de Mooij and R. Nahuis, 2004, "EU enlargement: Economic implications for countries and industries", in H. Berger, T. Moutos and H.-W. Sinn, eds., Managing EU Enlargement, Boston, Mass: The MIT Press, pp. 217-255.

Lejour, A. M., P. Veenendaal, G. Verweij and N. van Leeuwen, 2006a, "WorldScan: A Model for International Economic Policy Analysis", CPB Document, No. 111, The Hague: CPB Netherlands Bureau for Economic Policy Analysis.

Lejour, A. M., V. Solanic and P. J. G. Tang, 2006b, "EU accession and income growth: an empirical approach", CPB Discussion Paper, No. 72, The Hague: CPB Netherlands Bureau for Economic Policy Analysis.

MFAEI (Ministry of Foreign Affairs and European Integration of the Republic of Croatia), 2007, Overview of Progress in Negotiations, http://www.eupregovori.hr/files/Progress_in_EU-Croatia_negotiations_at_a_glance-2007-07-26-ENA4R.pdf.

OECD, 2006, OECD Investment Compact's Investment Reform Index Report 2006 (for SouthEast Europe), Paris: OECD.

Stabilisation and Association Agreement, 2001, http://ec.europa.eu/enlargement/key_documents/sap_en.htm and http://www.mvpei.hr/ei/download/2001/08/02/SAACouncilProposal.pdf.

United Nations, 2004, World Population Prospects, the 2002 revision, New York: United Nations.

UNCTAD, 2006, World Investment Report, Geneva: UNCTAD, http://www.unctad.org/wir.

World Bank, 2006, “Croatia: Living Standards Assessment”, Vol. 2: Background Papers, Washington, D.C.: World Bank, http://siteresources.worldbank.org/INTCROATIA/Resources/CroatiaLSA_Vol2.pdf. 
Popis objavljenih Radnih materijala ElZ-a / Previous issues in this series

2007

ElZ-WP-0701 Andrea Mervar and James E. Payne: An Analysis of Foreign Tourism Demand for Croatian Destinations: Long-Run Elasticity Estimates

EIZ-WP-0702 Sonja Radas and Mario Teisl: An Open Mind Wants More: Opinion Strength and the Desire for Genetically Modified Food Labeling Policy

EIZ-WP-0703 Maruška Vizek and Tanja Broz: Modelling Inflation in Croatia

EIZ-WP-0704 Danijel Nestić: Differing Characteristics or Differing Rewards: What is Behind the Gender Wage Gap in Croatia? 
ISSN 1846-4238 